\title{
Effect of Different Concentrations of Foliar Applications of Urea, NAA and Ethrel on Fruit Thinning of 'Dolce' Olive cv.
}

\author{
I.M.S. Osman \\ Olive and Semiarid Zone Fruits Department, Horticulture \\ Research Institute, Agricultural Research Centre, Cairo, \\ Egypt.
}

\begin{abstract}
7 HIS EXPERIMENT was executed in an olive private farm in Cairo Alexandria desert road (64 kilometer) to study the effect of spraying with Urea at $2 \%$ and $4 \%$, NAA at $100 \mathrm{mg} . \mathrm{L}^{-1}$ and 150 mg. $\mathrm{L}^{-1}$ and Ethrel at $150 \mathrm{mg} . \mathrm{l}^{-1}$ and $300 \mathrm{mg} . \mathrm{l}^{-1}$ on 'Dolce' olive cv. trees ( 7 years-old) were planted $6 \times 4 \mathrm{~m}$ and irrigated with drip irrigation. The farm received the recommended managements of Horticulture Research Institute publication (2011). As for thinning NAA with at $150 \mathrm{mg} \cdot \mathrm{l}^{-1}$ concentration gave the might percentage of thinning, however the foliar application of urea $2 \%$ concentration and Ethrel at $150 \mathrm{mg} . \mathrm{l}^{-1}$ gave the least ratios and the rest of the treatments showed the middle values between them. The remaining fruits per meter before harvesting were less when sprayed with NAA with at $150 \mathrm{mg} . \mathrm{l}^{-1}$ concentration, also the highest thinning ratios was before harvesting (resulted from thinning + June dropping + dropping before harvesting) in both seasons. It is obvious that spraying NAA with at $150 \mathrm{mg}$. $1^{-1}$ concentration leads to the increasing significantly of the length, diameter and weight in addition to the fruit volume and yield during the two growing seasons. Although those treatments didn't gave any significant difference in the fruit moisture percentage, spraying with NAA gave the highest significant difference in oil percentage as dry weight. Depending on these results we can recommend the spraying of NAA with at $150 \mathrm{mg}^{-1} \mathrm{l}^{-1}$ concentration to improve the production and quality of "Dolce" olive fruits through thinning.
\end{abstract}

Keywords: Urea, Naphthaline acetic acid, Ethrel, Olive 'Dolce' cv., Oil percentage and Yield.

Fruit thinning has been used for many years. Heavy crop load can result in fruits with small size and poor quality, breakage of limbs, exhaustion of tree reserves and reduced cold hardiness (Dennis, 2000). Fruit trees are often affected by spring frost. So, fruit thinning must to be done on time after fruit blooming (Bolat and Karlidağ, 1999) and as reported earlier (Surányi, 1982), best results gained when fruit thinning was applied after the danger of spring frost was averted. The discovery of plant hormones and their ability to regulate all aspects of growth and development were defining moments in horticulture (Greene, 2010). 
Urea induced fruitlet abscission in apricot trees and its effect was the same as NAA. Urea significantly reduced fruit set in peaches and nectarines (Zilkah et al., 1988), and pistachio (Rahemi and Ramezanian, 2007). Estembridge and Gambrell (1971) found that for peach cultivars, application of Ethrel at 100 to $150 \mathrm{mg} \mathrm{l}^{-1}$ in endosperm cytokines is stage resulted in sufficient thinning.

Certain endogenous hormones are involved in there gulation of fruit setting in many fruits. Plant growth regulating chemicals like naphthalene acetic acid (NAA) may be used to increase fruit set of certain fruit crops like apples, dates, and citrus and olive. Plant growth regulating hormones like naphthalene acetic acid alone and/or combined with other managerial operations may be playing an important role in fruit production and quality of olive (Khalil et al., 2012). Thomas (1982) said that to have successful thinning NAA must be sprayed 1218 days after full blooming. Spraying NAA affected percentage of thinning and fruit quality (Bolat and Karlidag, 1999). Ethrel is a follow up thinner when prior chemical thinning agents have unsuccessful to thinning successfully (Byers, 2003).

The purpose of this study was to investigate the preferable effect of urea, NAA or Ethrel on thinning of "Dolce" cv. to improve fruit quality.

To increase the fruit size normally the farmers practice hand thinning of fruit. But recently naphthalene acetic acid (NAA) has been reported to be useful for thinning of fruits (Agusti et al., 2000). It plays important roles in fruit formation and abscission, cell elongation, apical dominance, photoperiod and geotropism (Haidry et al., 1997).

\section{Material and Methods}

The present study was carried out during 2011 and 2012 growing seasons on 'Dolce' olive trees ( 7 years old), planted in a private farm at kilometer 64 from Cairo (Cairo Alexandria desert road). These trees were uniform in shape and size as possible and planted $6 \times 4$ meters apart and grown in sandy loam soil and irrigated with drip irrigation from well (underground water). Trees received the normal of organic and chemical fertilizers in winter at the beginning of November and the chemical fertilization program during the growing season. Also irrigation and pest control program were executed according to the recommendation in olive and semiarid Dept. in Horticulture Research Institute, ARC (Elsayed and Abou-Shanab, 2011).

The research study included the effect of foliar applications of urea (at $46 \%$ concentration) $2 \%$ and $4 \%$, Naphthalin acetic acid (NAA) 100 and $150 \mathrm{mg}^{-1}$, Ethrel at 150 and $300 \mathrm{mg} . \mathrm{l}^{-1}$ on thinning of "Dolce" olive cv. Spraying was executed 15 days after full bloom. The complete randomized design with three replicates per treatment (one tree of replicate) was adapted in this study. The following treatments were included: 
1- Control

2- Urea at $2 \%$

3-Urea at $4 \%$

4- NAA at $100 \mathrm{mg}^{-1} \mathrm{l}^{-1}$.

5- NAA at $150 \mathrm{mg} . \mathrm{l}^{-1}$.

6- Ethrel at $150 \mathrm{mg}$. $\mathrm{l}^{-1}$.

7- Ethrel at $300 \mathrm{mg}^{-1} \mathrm{l}^{-1}$.

\section{Measurements}

Growth parameters: At the beginning of the growing season (during first week of May) the Shoot length $(\mathrm{cm})$ was measured to relate the number of fruits.

Fruiting: Number of fruit set before spraying at the beginning of May, and number of fruits after spraying in mid June and before harvesting at the beginning of September were measured per meter.

Fruit quality: Thirty fruits per tree were randomly selected for carrying out the fruit quality measurements:

Fruit length $(\mathrm{cm})$, fruit diameter $(\mathrm{cm})$ and volume, fruit weight $(\mathrm{g})$, flesh weight (g.), seed length $(\mathrm{cm})$, seed diameter $(\mathrm{cm})$, seed weight $(\mathrm{g})$.

Yield: average yield per tree was calculated from each treatment $(\mathrm{Kg} /$ tree $)$.

Oil percentage as dry weight. By means of soxhalt extraction apparatus using petroleum ether as described by A.O.A.C. (1975).

Statistical analysis

The experiment included in this study followed a complete randomized design in factorial experiment. The obtained data was subjected to analysis of variance (ANOVA) according to Snedecor and Cochran (1980). Differences between treatments were compared by Duncan's multiple range test described in the SAS (SAS, 1986).

\section{Results and Discussion}

Number of fruits/m and fruit drop percentage

Concerning the effect of foliar application (15 days after full bloom) of urea at $2 \%$ and $4 \%, \mathrm{NAA}$ at 100 and $150 \mathrm{mg} . \mathrm{l}^{-1}$, Ethrel at 150 and $300 \mathrm{mg}^{-1}$ on "Dolce" cv. shoot length, number of fruit before spraying and after June drop and before harvesting during 2011 and 2012 seasons, data presents in Tables 1 and 2. As for number of fruits after spraying, control, urea at $2 \%$ gave the highest significant differences in 2011 season, meanwhile Ethrel at $150 \mathrm{mg}^{-1}$ performed the highest significant difference after spraying, after June drop and before harvesting compared to other treatments in both seasons. Whereas, percent of fruit thinning after spraying, after June drop and before harvesting showed the superior values as affected by NAA at 150 ppm during 2011 and 2012 seasons. These results consistent with (Zilkah et al., 1988) who found that, thinning of peaches and nectarines with different concentrations of urea. These results go also in line with those of 
Taghipour and Rahemi,(2009 and 2010), Taghipour et al. (2011) and Bonghi, et al. (2002).

TABLE 1. The effect of foliar applications of different concentrations of urea, Naphthaline acetic acid and Ethrel on number of fruits/m and fruit drop percentage "Dolce" olive cv. during 2011 growing season.

\begin{tabular}{|c|c|c|c|c|c|c|c|}
\hline \multirow[b]{2}{*}{ 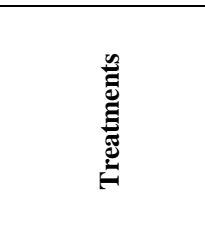 } & \multicolumn{7}{|c|}{2011 season } \\
\hline & 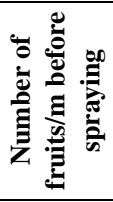 & 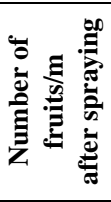 & 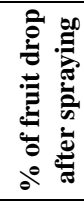 & 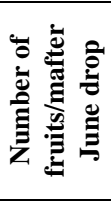 & 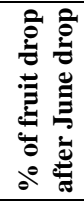 & 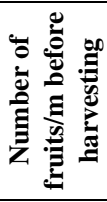 & 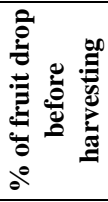 \\
\hline Control & 59.44 & $55.70 \mathrm{a}$ & $6.08 \mathrm{~d}$ & 48.60ab & $18.18 \mathrm{~d}$ & 47.33ab & $20.39 \mathrm{~d}$ \\
\hline Urea $2 \%$ & 56.74 & $51.23 \mathrm{a}$ & $8.99 \mathrm{~d}$ & $45.11 \mathrm{~b}$ & $19.90 \mathrm{~d}$ & $43.96 \mathrm{~b}$ & $22.06 \mathrm{~d}$ \\
\hline Urea 4\% & 55.11 & $46.13 b$ & $16.30 \mathrm{~d}$ & $34.24 \mathrm{c}$ & $37.83 \mathrm{c}$ & $34.46 \mathrm{c}$ & $37.07 \mathrm{c}$ \\
\hline NAA $100 \mathrm{mg} \cdot \mathrm{L}^{-1}$ & 67.37 & $37.94 \mathrm{c}$ & $43.85 \mathrm{~b}$ & $35.49 \mathrm{c}$ & $47.41 \mathrm{~b}$ & $34.69 \mathrm{c}$ & $48.61 \mathrm{~b}$ \\
\hline NAA $150 \mathrm{mg} \cdot \mathrm{L}^{-1}$ & 58.94 & $23.98 \mathrm{~d}$ & $58.45 \mathrm{a}$ & $21.00 \mathrm{~d}$ & $63.89 \mathrm{a}$ & $20.44 d$ & $64.88 \mathrm{a}$ \\
\hline Ethrel $150 \mathrm{mg} . \mathrm{L}^{-1}$ & 59.17 & $54.48 \mathrm{a}$ & $7.81 \mathrm{~d}$ & $49.98 \mathrm{a}$ & $16.05 \mathrm{~d}$ & $49.27 \mathrm{a}$ & $17.26 \mathrm{~d}$ \\
\hline Ethrel $300 \mathrm{mg} . \mathrm{L}^{-1}$ & 56.89 & $41.79 b c$ & $27.09 \mathrm{c}$ & $37.68 \mathrm{c}$ & $34.09 \mathrm{c}$ & $38.64 \mathrm{c}$ & $37.57 \mathrm{c}$ \\
\hline L.S.D at $5 \%$ & & 4.434 & 10.05 & 3.813 & 6.587 & 4.294 & 6.678 \\
\hline
\end{tabular}

"Means followed by the same higher case letter within the same column are not significantly different, $\mathrm{p}=0.05$.

TABLE 2. The effect of foliar applications of different concentrations of urea, Naphthaline acetic acid and Ethrel on number of fruits/m and fruit drop percentage on "Dolce" olive cv. during 2012 growing season.

\begin{tabular}{|c|c|c|c|c|c|c|c|}
\hline \multirow[b]{2}{*}{ Treatments } & \multicolumn{7}{|c|}{2012 season } \\
\hline & 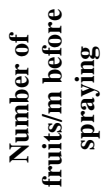 & 苍泀 & 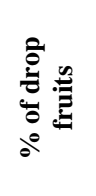 & 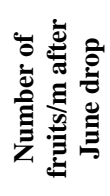 & 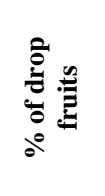 & 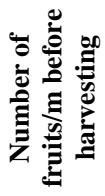 & 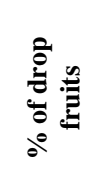 \\
\hline Control & 54.22 & $44.81 \mathrm{~b}$ & $17.25 b$ & $43.76 b$ & $19.24 d$ & $43.58 b$ & $19.53 \mathrm{~d}$ \\
\hline Urea $2 \%$ & 48.40 & $41.17 b$ & $14.91 b$ & $38.70 \mathrm{c}$ & $20.04 \mathrm{~cd}$ & $38.42 \mathrm{c}$ & $20.62 \mathrm{~cd}$ \\
\hline Urea $4 \%$ & 51.85 & $43.54 b$ & $16.10 \mathrm{~b}$ & $40.44 \mathrm{bc}$ & $21.59 \mathrm{~cd}$ & $40.36 b c$ & $22.16 \mathrm{~cd}$ \\
\hline NAA $100 \mathrm{mg} \cdot \mathrm{L}^{-1}$ & 35.03 & $29.27 \mathrm{c}$ & $17.04 \mathrm{~b}$ & $23.27 \mathrm{~d}$ & $33.85 \mathrm{~b}$ & $23.13 d$ & $34.19 \mathrm{~b}$ \\
\hline NAA $150 \mathrm{mg} \cdot \mathrm{L}^{-1}$ & 23.76 & $17.32 \mathrm{~d}$ & $27.68 \mathrm{a}$ & $14.42 \mathrm{f}$ & $39.68 \mathrm{a}$ & $14.42 \mathrm{e}$ & $39.68 \mathrm{a}$ \\
\hline Ethrel $150 \mathrm{mg} . \mathrm{L}^{-1}$ & 65.26 & $53.87 \mathrm{a}$ & $17.42 \mathrm{~b}$ & $50.53 a$ & $22.54 \mathrm{c}$ & $50.41 \mathrm{a}$ & $22.74 \mathrm{c}$ \\
\hline Ethrel $300 \mathrm{mg} . \mathrm{L}^{-1}$ & 28.81 & $22.01 \mathrm{~d}$ & $24.33 \mathrm{a}$ & $19.70 \mathrm{e}$ & $32.50 \mathrm{~b}$ & $19.41 \mathrm{~d}$ & $33.34 \mathrm{~b}$ \\
\hline L.S.D at $5 \%$ & & 4.896 & 5.968 & 3.424 & 2.928 & 4.131 & 2.613 \\
\hline
\end{tabular}

*Means followed by the same higher case letter within the same column are not significantly different, $\mathrm{p}=0.05$.

Fruit and seed dimensions

Data in Tables 3 and 4 presents fruit dimensions (fruit length and diameter, fruit weight, seed weight, seed length and diameter) of Dolce olive cv. during 2011 and 2012 seasons. It is obvious that NAA at $150 \mathrm{mg}$. $\mathrm{l}^{-1}$ increased 
significantly fruit and seed length, diameter and weight compared to the control and other treatments in both seasons. Whereas, Ethrel at $150 \mathrm{mg} . \mathrm{l}^{-1}$ increased significantly the seed length, control and urea at $2 \%$ increased significantly seed diameter in the first season. Meantime, NAA at $100 \mathrm{mg} . \mathrm{l}^{-1}$ gave the same effect on seed and fruit weight during 2011 season.

TABLE 3. The effect of foliar applications of different concentrations of urea, Naphthaline acetic acid and Ethrel on fruit and seed dimensions of "Dolce" olive cv. during 2011 growing season.

\begin{tabular}{|c|c|c|c|c|c|c|}
\hline \multirow[b]{2}{*}{ Treatments } & \multicolumn{6}{|c|}{2011 season } \\
\hline & $\begin{array}{c}\text { Fruit } \\
\text { length } \\
(\mathbf{c m})\end{array}$ & $\begin{array}{c}\text { Fruit } \\
\text { diameter } \\
(\mathbf{c m})\end{array}$ & $\begin{array}{c}\text { Fruit } \\
\text { weight } \\
\text { (g) }\end{array}$ & $\begin{array}{c}\text { Seed } \\
\text { length } \\
(\mathrm{cm})\end{array}$ & $\begin{array}{c}\text { Seed } \\
\text { diameter } \\
(\mathbf{c m})\end{array}$ & $\begin{array}{c}\text { Seed } \\
\text { Weight } \\
\text { (g) }\end{array}$ \\
\hline Control & $3.28 \mathrm{~b}$ & $1.53 \mathrm{~cd}$ & $3.94 \mathrm{~b}$ & $2.07 \mathrm{~b}$ & $0.700 \mathrm{a}$ & $0.543 \mathrm{~cd}$ \\
\hline Urea $2 \%$ & $3.14 \mathrm{c}$ & $1.63 \mathrm{~b}$ & $3.78 \mathrm{~b}$ & $2.06 \mathrm{~b}$ & $0.703 \mathrm{a}$ & $0.497 \mathrm{~d}$ \\
\hline Urea 4\% & $3.09 \mathrm{c}$ & $1.50 \mathrm{~d}$ & $3.24 \mathrm{c}$ & $2.07 \mathrm{~b}$ & $0.663 \mathrm{c}$ & $0.487 \mathrm{~d}$ \\
\hline NAA $100 \mathrm{mg} \cdot \mathrm{L}^{-1}$ & $3.13 \mathrm{c}$ & $1.61 b c$ & $4.63 \mathrm{a}$ & $2.10 \mathrm{~b}$ & $0.687 \mathrm{ab}$ & $0.727 \mathrm{a}$ \\
\hline NAA $150 \mathrm{mg} \cdot \mathrm{L}^{-1}$ & $3.41 \mathrm{a}$ & $1.76 \mathrm{a}$ & $4.84 \mathrm{a}$ & $2.26 \mathrm{a}$ & $0.703 a$ & $0.747 \mathrm{a}$ \\
\hline Ethrel $150 \mathrm{mg} \cdot \mathrm{L}^{-1}$ & $2.81 \mathrm{~d}$ & $1.51 \mathrm{~d}$ & $2.79 \mathrm{~d}$ & $2.30 \mathrm{a}$ & $0.693 \mathrm{ab}$ & $0.653 \mathrm{~b}$ \\
\hline Ethrel $300 \mathrm{mg} \cdot \mathrm{L}^{-1}$ & $2.82 \mathrm{~d}$ & $1.48 \mathrm{~d}$ & $2.79 \mathrm{~d}$ & $2.11 \mathrm{~b}$ & $0.680 \mathrm{bc}$ & $0.557 \mathrm{c}$ \\
\hline L.S.D at $5 \%$ & 0.126 & 0.080 & 0.264 & 0.149 & 0.018 & 0.056 \\
\hline
\end{tabular}

"Means followed by the same higher case letter within the same column are not significantly different, $\mathrm{p}=0.05$.

TABLE 4. The effect of foliar applications of different concentrations of urea, Naphthaline acetic acid and Ethrel on fruit and seed dimensions of "Dolce" olive cv. during 2012 growing season.

\begin{tabular}{|c|c|c|c|c|c|c|}
\hline \multirow[b]{2}{*}{ Treatment } & \multicolumn{6}{|c|}{2012 season } \\
\hline & $\begin{array}{c}\text { Fruit } \\
\text { length } \\
(\mathbf{c m})\end{array}$ & $\begin{array}{c}\text { Fruit } \\
\text { diameter } \\
(\mathbf{c m})\end{array}$ & $\begin{array}{c}\text { Fruit } \\
\text { weight } \\
\text { (g) }\end{array}$ & $\begin{array}{c}\text { Seed } \\
\text { length } \\
(\mathrm{cm})\end{array}$ & $\begin{array}{c}\text { Seed } \\
\text { diameter } \\
(\mathbf{c m})\end{array}$ & $\begin{array}{c}\text { Seed } \\
\text { Weight } \\
\text { (g) }\end{array}$ \\
\hline Control & $3.28 b$ & $1.53 \mathrm{~cd}$ & $3.94 b$ & $2.60 \mathrm{a}$ & $0.743 b$ & $0.837 \mathrm{a}$ \\
\hline Urea $2 \%$ & $3.14 \mathrm{c}$ & $1.63 \mathrm{~b}$ & $3.78 b$ & $2.33 b$ & $0.747 \mathrm{~b}$ & $0.710 \mathrm{bc}$ \\
\hline Urea $4 \%$ & $3.09 \mathrm{c}$ & $1.50 \mathrm{~d}$ & $3.24 \mathrm{c}$ & $2.28 b$ & $0.697 \mathrm{~cd}$ & $0.640 \mathrm{c}$ \\
\hline NAA $100 \mathrm{mg} . \mathrm{L}^{-1}$ & $3.13 \mathrm{c}$ & $1.61 \mathrm{bc}$ & $4.63 a$ & $2.43 \mathrm{ab}$ & $0.730 \mathrm{~b}$ & $0.773 \mathrm{ab}$ \\
\hline NAA $150 \mathrm{mg} . \mathrm{L}^{-1}$ & $3.41 \mathrm{a}$ & $1.76 \mathrm{a}$ & $4.84 \mathrm{a}$ & $2.57 \mathrm{a}$ & $0.813 \mathrm{a}$ & $0.803 \mathrm{a}$ \\
\hline Ethrel $150 \mathrm{mg} . \mathrm{L}^{-1}$ & $2.81 \mathrm{~d}$ & $1.51 \mathrm{~d}$ & $2.79 d$ & $2.03 c$ & $0.707 \mathrm{c}$ & $0.493 \mathrm{~d}$ \\
\hline Ethrel $300 \mathrm{mg} . \mathrm{L}^{-1}$ & $2.82 d$ & $1.48 \mathrm{~d}$ & $2.79 \mathrm{~d}$ & $2.01 \mathrm{c}$ & $0.680 \mathrm{~d}$ & $0.510 \mathrm{~d}$ \\
\hline L.S.D at $5 \%$ & 0.126 & 0.080 & 0.264 & 0.169 & 0.019 & 0.080 \\
\hline
\end{tabular}

"Means followed by the same higher case letter within the same column are not significantly different, $\mathrm{p}=0.05$.

Meanwhile, NAA (mg. $\mathrm{l}^{-1}$ ) increased significantly fruit weight; in addition the control increased significantly seed length and weight during 2011 and 2012 seasons. Noor et al. (1995), Mistra \& Datta, (2001) and Levin \& Lavee, (2005) reported that NAA improved number of inflorescence flower number fruit setting and fruit size. 
Fruit moisture, flesh weight and volume, oil \% and yield

As regard to, fruit flesh weight (g) and volume, moisture \%, oil \% and yield (kg/tree) were presented in Tables 5 and 6 in 2011 and 2012 seasons. It is obvious that NAA at $150 \mathrm{mg} . \mathrm{l}^{-1}$ increased significantly fruit volume, flesh weight (g.) and yield $(\mathrm{kg} /$ tree) in comparison with the control and other treatments in both seasons, as oil \% as fresh weight (g.) didn't show any significant differences in the first season but only oil \% as dry weight $(\mathrm{g})$ in the second season, Ethrel at $\left(\mathrm{mg} . \mathrm{l}^{-1}\right)$ performed the least significant differences of moisture content $(\%)$ and oil $\%$ as dry weight $(\mathrm{g})$ in the first season and yield in both seasons.

TABLE 5. The effect of foliar applications of different concentrations of urea, Naphthaline acetic acid and Ethrel on fruit volume, flesh weight (g.), moisture content $(\%)$, oil $(\%)$ and yield $(\mathrm{kg} /$ tree) of "Dolce" olive cv during 2011 growing season.

\begin{tabular}{|c|c|c|c|c|c|c|}
\hline \multirow[b]{2}{*}{ Treatments } & \multicolumn{6}{|c|}{2011 season } \\
\hline & $\begin{array}{c}\text { Fruit } \\
\text { volume }\end{array}$ & $\begin{array}{c}\text { Flesh } \\
\text { weight } \\
\text { (g) }\end{array}$ & $\begin{array}{c}\text { Moisture } \\
\text { content } \\
\% \\
\end{array}$ & $\begin{array}{c}\text { Oil \% } \\
\text { as fresh } \\
\text { weight }\end{array}$ & $\begin{array}{c}\text { Oil \% as } \\
\text { dry } \\
\text { weight }\end{array}$ & Yield(kg)/ee \\
\hline Control & $3.70 \mathrm{c}$ & 2.68d & $65.66 \mathrm{a}$ & 16.11a & 46.92a & $50.00 \mathrm{c}$ \\
\hline Urea $2 \%$ & $3.47 \mathrm{c}$ & $2.48 \mathrm{de}$ & $65.66 \mathrm{a}$ & $16.12 \mathrm{a}$ & $46.94 a$ & $47.67 \mathrm{c}$ \\
\hline Urea $4 \%$ & $3.60 \mathrm{c}$ & $2.40 \mathrm{e}$ & $65.84 \mathrm{a}$ & $16.13 \mathrm{a}$ & $47.23 \mathrm{a}$ & $52.67 \mathrm{~b}$ \\
\hline NAA $100 \mathrm{mg} . \mathrm{L}^{-1}$ & $4.73 b$ & $3.65 b$ & $65.71 \mathrm{a}$ & $16.31 \mathrm{a}$ & $47.56 \mathrm{a}$ & $55.00 \mathrm{ab}$ \\
\hline NAA $150 \mathrm{mg} . \mathrm{L}^{-1}$ & $5.20 \mathrm{a}$ & $4.20 \mathrm{a}$ & $65.73 a$ & $16.23 \mathrm{a}$ & $47.38 \mathrm{a}$ & $56.00 \mathrm{a}$ \\
\hline Ethrel $150 \mathrm{mg} . \mathrm{L}^{-1}$ & $4.40 \mathrm{~b}$ & $3.26 \mathrm{c}$ & $62.70 \mathrm{~b}$ & $16.24 \mathrm{a}$ & $43.89 \mathrm{~b}$ & $35.00 \mathrm{~d}$ \\
\hline Ethrel $300 \mathrm{mg} . \mathrm{L}^{-1}$ & $3.57 \mathrm{c}$ & $2.65 \mathrm{de}$ & $65.39 \mathrm{a}$ & $16.44 \mathrm{a}$ & $47.42 \mathrm{a}$ & $52.67 \mathrm{~b}$ \\
\hline L.S.D at $5 \%$ & 0.351 & 0.264 & 1.051 & N.S. & 1.565 & 2.409 \\
\hline
\end{tabular}

"Means followed by the same higher case letter within the same column are not significantly different, $\mathrm{p}=0.05$.

TABLE 6. The effect of foliar applications of different concentrations of urea, Naphthaline acetic acid and Ethrel on fruit volume, flesh weight (g.), Moisture content (\%), oil (\%) and yield (kg/tree) of "Dolce" olive cv during 2012 growing season.

\begin{tabular}{|c|c|c|c|c|c|c|}
\hline \multirow[b]{2}{*}{ Treatments } & \multicolumn{6}{|c|}{2012 season } \\
\hline & $\begin{array}{c}\text { Fruit } \\
\text { volume }\end{array}$ & $\begin{array}{c}\text { Flesh } \\
\text { weight } \\
\text { (g) }\end{array}$ & $\begin{array}{c}\text { Moisture } \\
\text { content } \\
\%\end{array}$ & $\begin{array}{c}\text { Oil \% as } \\
\text { fresh } \\
\text { weight }\end{array}$ & $\begin{array}{c}\text { Oil \% as } \\
\text { dry } \\
\text { weight }\end{array}$ & $\begin{array}{c}\text { Yield } \\
(\mathrm{kg}) / \text { tree }\end{array}$ \\
\hline Control & $4.43 b$ & $3.10 \mathrm{~b}$ & $65.55 \mathrm{a}$ & $16.00 \mathrm{a}$ & $46.44 b c$ & $51.00 \mathrm{c}$ \\
\hline Urea $2 \%$ & $4.13 b c$ & $3.07 \mathrm{~b}$ & $66.05 \mathrm{a}$ & $15.86 \mathrm{a}$ & $46.72 b c$ & $54.00 \mathrm{~b}$ \\
\hline Urea $4 \%$ & $3.77 \mathrm{c}$ & $2.60 \mathrm{c}$ & $66.42 \mathrm{a}$ & $16.10 \mathrm{a}$ & $47.95 \mathrm{ab}$ & $56.00 \mathrm{ab}$ \\
\hline NAA $100 \mathrm{mg} . \mathrm{L}^{-1}$ & $5.00 \mathrm{a}$ & $3.86 \mathrm{a}$ & $65.37 \mathrm{a}$ & $15.97 \mathrm{a}$ & $46.11 \mathrm{c}$ & $54.33 b$ \\
\hline NAA $150 \mathrm{mg} \cdot \mathrm{L}^{-1}$ & $5.23 \mathrm{a}$ & $4.04 \mathrm{a}$ & $66.45 a$ & $16.24 \mathrm{a}$ & $49.12 \mathrm{a}$ & $58.00 \mathrm{a}$ \\
\hline Ethrel $150 \mathrm{mg} . \mathrm{L}^{-1}$ & $3.10 \mathrm{~d}$ & $2.30 \mathrm{c}$ & $65.93 \mathrm{a}$ & $16.09 \mathrm{a}$ & $47.22 b c$ & $45.33 d$ \\
\hline Ethrel $300 \mathrm{mg} . \mathrm{L}^{-1}$ & $3.80 \mathrm{c}$ & $2.28 \mathrm{c}$ & $66.21 \mathrm{a}$ & $15.81 \mathrm{a}$ & $46.79 b c$ & $50.33 c$ \\
\hline L.S.D at $5 \%$ & 0.386 & 0.308 & N.S. & N.S. & 1.634 & 2.387 \\
\hline
\end{tabular}

${ }^{*}$ Means followed by the same higher case letter within the same column are not significantly different, $\mathrm{p}=0.05$.

Egypt. J. Hort. Vol. 40, No. 1 (2013) 
Although, moisture content (\%) and oil \% as fresh weight (g) didn’t show any significant differences, NAA at $\left(150 \mathrm{mg}^{-1}\right)$ gave the highest and significant value of oil \% as dry weight during 2012 season.

\section{Conclusion and Discussion}

These results are coincide with those of Ryan et al. (2002), Bianchi (2003) and Khalil et al. (2012), Variable response of plant growth regulators (PGRs) might be due to fact that PGRs role depends upon the time of application, concentration and absorbed quantity (Rajput and Haribabu, 1985). Moreover, NAA effects might be due to that to an improve of the internal hormonal and carbohydrate level of the canopy which is responsible for improving number of inflorescence (Levin and Lavee, 2005), flower number (Noor et al., 1995) fruit setting and fruit size in Kalamata olive cv. (Proietti \& Tombesi, 1990 and Petrisou and Voyiatzis, 1994). Similarly, Mistra and Datta (2001). Ethrel effectively induced fruit abscission. As Ethrel is absorbed by the tissue, its hydrolysis occurs and released Ethylene induces abscission by elevating respiration rate and production of enzymes which hydrolyze cellulose in the abscission layer (Wolpert and Ferguson, 1990).

Conclusively, spraying NAA at $150 \mathrm{mg} . \mathrm{l}^{-1}$ may improve the fruit production and quality of "Dolce" cv. through fruit thinning.

\section{References}

Agusti, M., Juan, M., Almela, V. and Gariglio, N. (2000) Loquat fruit size is increased through the thinning effect of naphthalene acetic acid. Plant GrowthRegul., 31, 167171 .

A.O.A.C. (1975) Official Methods Analysis, $\left(12^{\text {th }}\right.$ ed) .Association of Official Analytical Chemists Washington DC.

Bianchi, G. (2003) Lipids and phenols in table olives. Eur. J. Lipid Sci. Technol. 105, 229-242.

Bolat, I and Karlidağ, H (1999) Thinning by NAA and hand of 'Hacihaliloglu' and 'Hasanbey' apricot cultivars. Acta Hort., 488, 507-510.

Bonghi, C.M., Roja, P., Tonutti, A. and Romina, A. (2002) Ethephone, NAA and NAD as chemical thinners of pear fruitlets. Acta. Hort., 596, 217- 722.

Byers, R.E., Costa, G. and Viasotto, G. (2003) Flower and fruit thinning of peach and other prunus. Hort. Rev., 28, 351-392.

Dennis F.G. Jr (2000) The history of fruit thinning. J. plant Growth Regul., 31, 1-16.

Elsayed, M.E. and Abou Shanab, I.S. (2011) Olive Growing in Egypt. A pamphlet publication, Hort. Res. Inst., Giza, Egypt. 
Estembridge, G.E. and Gambrell, C.E. (1971) Thinning peaches with bloom and postbloom applications of 2-chloroethylphosphonic acid. J. Amer. Soc. Hort. Sci., 96, 7-10

Greene, D.W. (2010) The development and use of plant bioregulators in tree fruit production. Acta Hort., 884, 31-40.

Haidry, G.A. Jalal-ud-Din and Munir, M. (1997) Effect of NAA on fruit drop yield and quality of mango, Mangifera indic a cultivars Langra. Scientific Khyber, 10(1), 13-20.

Khalil, F., Khalid M.Q., Fakhar-U.H. and Nabila B. (2012) Effect of girdling and plant growth regulators on productivity in olive (olea europaea). Pakistan J. Agric. Res., 25(2), 120-128 pp.

Levin, A.G. and Lavee, S. (2005) The influence of girdling on flower type number, inflorescence density, fruit set and yield in three olive cultivars. (Barnea, Picual and Souri) Australian J. Agric. Res., 56 (8), 827-831.

Mistra, P. and Datta, S.K. (2001) Direct differentiation of shoot buds in leaf segments of whit marigold (Tagetes erecta L.). In Vitro Cellular and Development biology-Plant, 37, 466-470

Noor, M.A. Caudhary, M.I., Virk, N.A. and Amjad, M. (1995) Effect of girdling and nutrition on flowering, fruit set and yield of olive (Olea europaea L.). Pakistan J.Sci., 47(3-4), 82-84.

Petrisou, M. and Voyiatzis, D. G. (1994) The beneficial effect of girdling, auxin, tween20 and paclobutrazol on the propagation of olive by an improved method of mountlayering. ActaHort., 356, 24-27

Proietti, P. and Tombesi, A. (1990) Effect of girdling on photosynthetic activity in olive leaves.Acta Hort.,186, 215-218.

Rahemi, M. and Ramezanian, A. (2007) potential of ethephon, NAA, NAD, and urea for thinning pistachio fruitlets. Sci. Hort., 111, 160-163.

Rajput, C.B.S. and Haribabu, R.S. (1985) Citriculture, Kalyani publishers, New Delhi.

Ryan, D., Antolovich, M., Prenzler, P., Robards, K. and Lavee, S. (2002) Biotransformations of phenolic compounds in Olea europaea L. Scientia Horticultura, 92, $147-$ 176.

Sas, Institute. (1986) SAS Users Guide Statistics. $6^{\text {th }}$ ed., SAS. Institute Inc. Cary. NC. USA.

Snedecor, G.W. and Cochran, W.G. (1980) Statistical Methods, $7^{\text {th }}$ ed. Iowa. State Univ. Press, Ames, Iowa, USA, p. 507.

Surányi, D. (1982) Chemical thinning results of apricots. Acta Hort., 121, 335-339. 
Taghipour, L. and Rahemi, M. (2009) Evaluation the effects of some chemical agents on thinning percent and quality of apricot cv. 'Khiary' (Prunus armeniaca L). J. Hort.Sci. 23, 78-84 (in persian).

Taghipour, L. and Rahemi, M. (2010) The influence of fruit thinning on the apricot cultivar 'Gerdi'. Research J. Environ. Sci., 4, 467-472.

Taghipour, L., Majid Rahemi and Pedram Assar (2011) Thinning with NAA, NAD, ethephon, urea and by hand to improve fruit quality of 'Gerdi' apricot. Braz. J. Plant Physiol., 23(4), 279-284.

Thomas, T.H. (1982) Plant Growth Regulator Potential and Practice. British Crop Protection Council. UK. ISBN 10. 0901436690271 p.

Wolpert, J.A. and Ferguson, L. (1990) Inflorescence bud retention in Kerman pistachio: effects of defruiting date and branch size. HortScience, 25, 919-921.

Zilkah, S., Klein, I. and David, I. (1988) Thinning peaches and nectarines with urea. $J$. Hort. Sci., 63, 209-216.

(Received 28/3/2013

accepted 26/5/2013) 
تأثير الرش بتركيزات مختلفة من اليوريا ونفثالين حامض الخليك

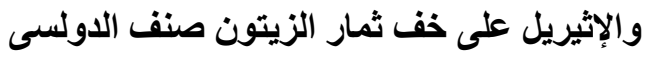

$$
\begin{aligned}
& \text { إبراهيم محمد سيد عثمان } \\
& \text { قسم بحوث الزيتون وفاكهة المناطق شبه الجافة ـ معهد بحوث البساتين ـ مركز }
\end{aligned}
$$

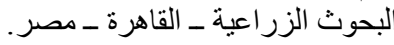

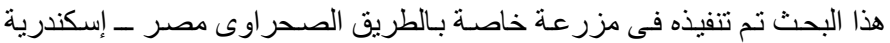

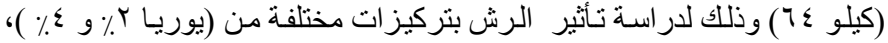

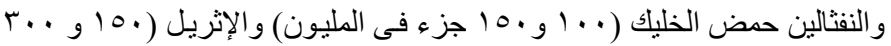

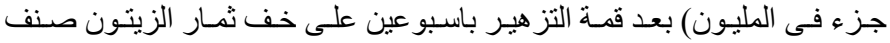

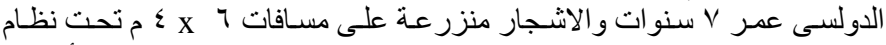

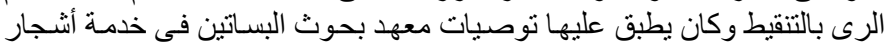

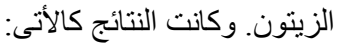

تم الحصـول على أعلى نسبة مئويـة للخف بالنفتـالين حمض الخليك بتركيز

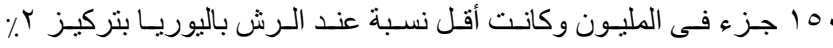

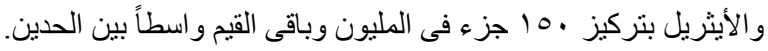

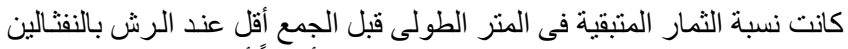

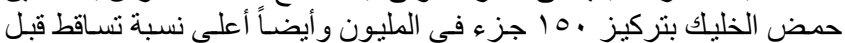

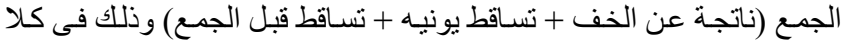
الموسمين.

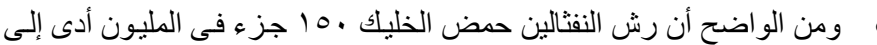

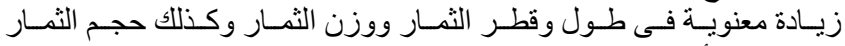

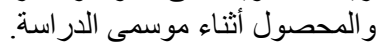

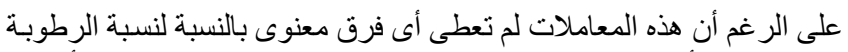

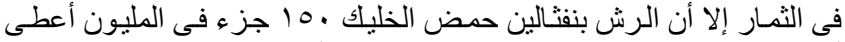
أعلى قيمة معنوية من النسبة المئوية للزيت على النى أساس الوزن الجن الجاف.

وبناءً على هذه النتائج فإنه يمكن أن نوصى بـالرش بنفتالين حمض الخليك بتركيز

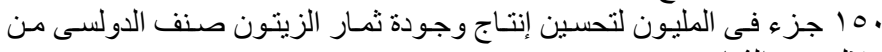
خلال خف الثمار. 